\title{
Factors Affecting the Success of Incubators and the Moderating Role of Information and Communication Technologies
}

\author{
Qadri Alzaghal $^{\# 1}$, Muriati Mukhtar ${ }^{\# 2}$ \\ ${ }^{\#}$ Faculty of Information Science and Technology, The National University of Malaysia (UKM), Bangi, Selangor, 43600, Malaysia \\ E-mail: ${ }^{1}$ qadri.alzaghal@gmail.com, ${ }^{2}$ muriati@ukm.edu.my
}

\begin{abstract}
Business incubators can help young firms to survive during their first years. They are considered to be an entrepreneurial and economic development instrument that can increase the creativity of new firms including small and mid-sized enterprises and that can support them in the early stage of development which is the most vulnerable stage of their existence. Small and mid-sized enterprises are crucial for enhancing innovation, productivity, competitiveness, social cohesion, and economic development in developed and developing countries. They are also crucial in minimizing unemployment; they create a lot of jobs and significant output in many countries. The economy in many developing countries, especially Arab countries, is in a critical state. The unemployment rate is very high and gross domestic product is very low compared to developed countries. Many types of success models have been proposed and used to measure the success and performance of business incubators in developed countries. However, a limited number of studies and success models have been published on this topic in the case of the developing world. Therefore, the main objective of this paper is to propose a model using a combination of well-known and new success factors for business incubator success in developing countries.
\end{abstract}

Keywords - Business Incubator; information and communication technologies; SMEs; culture; Palestine.

\section{INTRODUCTION}

Innovation, entrepreneurship, and incubators are very attractive topics to researchers, students, and youth in general around the world, and they require more attention. Innovation and entrepreneurship are also essential elements in the transition to a knowledge-based economy and to success in future business competition [1]. Moreover, knowledge, technology, entrepreneurship, and innovation are on the agenda of countries seeking to improve the quality of life of their citizens [2]. Hence entrepreneurship, business, and innovation need to be nurtured during their earliest stages of development, so that they will be more successful [3].

There is a strong relationship between innovation, entrepreneurship, incubators, and business. In fact, business incubators are an important economic strategy that is used to develop new and emerging social and economic opportunities for the creation and commercialization of new products, new processes, and new business models. This strategy leads to several elements such as creativity, innovation, and entrepreneurship that have a relationship with business incubation models [4], [5].

Currently, developing countries, and especially Arab countries, are facing a very bad economic situation. The unemployment rate in Arab countries, especially in Bilad ElSham (Levant), is very high compared to that in developed countries (e.g. Fig. 1). Also, gross domestic product (GDP) in Arab countries is very low compared to that in developed countries (e.g. Fig. 2).

The geopolitical and socio-economic situation in Palestine is also critical for many reasons including the Israeli occupation since 1967, and the unemployment rate is very high and the level value of per capita is very low. One of the proposed solutions is the creating of small and mid-sized enterprises (SMEs) through the use of incubators.

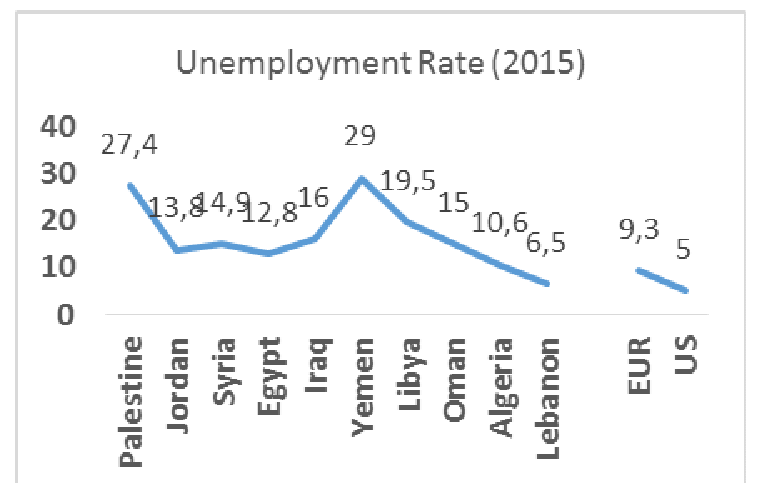

Fig. 1 Unemployment rate in some Arab countries, Europe, and the United States 


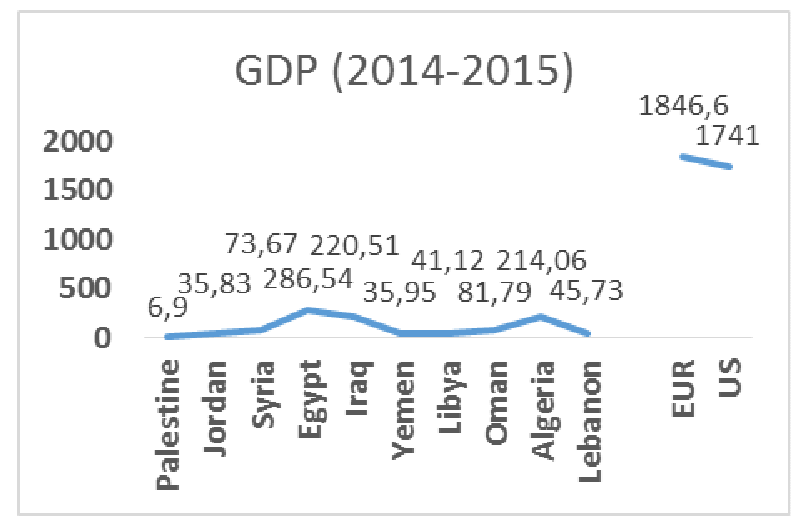

Fig. 2 Gross domestic product (GDP) in some Arab countries, Europe, and the United States

Small and mid-sized enterprises are crucial in enhancing innovation, productivity, competitiveness, employment generation, and social cohesion [6], [7]. However, there are some challenges in Arab countries regarding the inefficiency of the labor forse, financial markets, goods, and the low level of technological adaptation and innovation [8]. According to [8], the solution lies in the hands of SMEs which contribute to innovation and economic growth by providing employment opportunities, supporting the development of new forms of work organization, and fostering innovation and entrepreneurship.

Small and mid-sized enterprises are the main target of economic development policies in developed and developing countries locally, regionally, and nationally. They are crucial for creating jobs [9]-[12]. Business incubators can help young firms to survive during their first years, and they are considered to be an entrepreneurial and economic development instrument that can increase the creation of new firms including SMEs and support them in the early stage of development which is the most vulnerable stage of their existence [7], [8], [13]-[18].

\section{MATERIALS AND METHODS}

Currently, business incubators are crucial for developing countries because these countries are facing a very bad economic situation where the level value of per capita is very low and there are very few jobs available for the thousands of graduate students. Business incubators have proven to be very successful in promoting economic development and the employment growth around the world [19].

It has been concluded by [20] that, currently, industrialization is growing rapidly, particularly in developing countries, so studying the effectiveness of incubators from time to time is a promising way to understand and improve the industrial development process and also to determine whether incubation programs effectively facilitate the economic growth of communities.

\section{A. Incubators: History and Definitions}

According to [21], the first business incubator was established in 1959 in New York in the United States, but the idea of providing services and facilities for start-ups did not catch on until after the 1970s. In 1980 in the USA, there were just 12 incubators, but this increased to over 1250 by the end of 2012. Formally, the incubation definition got popular around the world in the media around 1999. At the end of 2012, there were nearly more than 7000 business incubators and programs worldwide, approximately 1800 of those incubators were in the USA and 900 in Europe. Furthermore, at the end of 2013, nearly 9000 business incubators were running worldwide [22].

In Palestine, the first two business incubators were established in 2004, they are the Palestine Information \& Communications Technology Incubator (PICTI) located in Ramallah and the Business Technology Incubator (BTI) located at the Islamic University in Gaza. Currently, there are about 22 incubators, accelerators, and centers of excellences as well as incubation and pre-incubations programs that are running in Palestine and offering incubation facilities. There are many difficulties in defining business incubators, not least because of the continuous growth in business incubation and the diversification of incubator components [23]. Incubators (for business, technology, information and communication technologies (ICT), etc.) have many definitions and are defined in various ways in the literature. This variation in defining business incubators is because of the diversity of incubators, their sponsors, and their purposes [24].

There is no one standard definition and type of business incubation. Thus, conceptually, a first-generation business incubator started as resource-sharing initiative, then became an important tool offering many business services such as coaching, training, consulting, access to funding, networking, etc. Moreover, in the literature, the many definitions and types reflect different aspects of national policies and cultures and there are many types of business services, approaches, and objectives that are covered by business incubators [25].

Incubators are designed to provide a variety of resources that will increase the odds that a new business will succeed, and in that success, there will be some economic benefits derived from the sponsoring entity [26]. Moreover, a business incubator has been defined as "an environment formally designed to stimulate the growth and development of new and early stage firms by improving their opportunities for the acquisition of resources aimed at facilitating the development and commercialization of new products, new technologies, and new business models" [27]. It is also defined by [25] as a facility founded to create a conducive environment to new ventures to help them to cope with the difficulties that exist in the initial stage of the business life cycle, to help them to survive and grow to become successful mature businesses. Finally, a business incubator has been described as an organization established to accelerate the success and growth of entrepreneurial companies, through presenting a group of resources and services such as a physical space, capital, coaching, common services, and networking connections [28].

\section{B. Role of Incubators and SMEs in Economic Development}

Business incubators are very important for start-ups, especially technology-based companies, and can offer many services and tools to them. According to [17], nowadays many studies have confirmed that the concept of incubation has enabled a number of developed countries to initiate 
business policies that support economic development and sustainable economic growth, and to convert those policies into business, which is an important step in minimizing unemployment. Also, [29] found that many previous studies have identified the vital contribution that SMEs make to employment, GDP, rural development, and overall economic development. As an example, in Malaysia, the contribution of SMEs to economic development is projected to generate more than $99.2 \%$ of total business establishments, a $41 \%$ share of GDP, a $62 \%$ share of employment, and a $25 \%$ share of total exports by 2020 .

In an e-mail interview conducted by the researcher, Eng. Hasan Omar the co-founder and CEO of Glow Innovations in Palestine said SMEs and an innovation economy are the solution to the high unemployment rate, especially among youth who represent more than $50 \%$ of population, and to the existing socio-economic and geopolitical restrictions as well as other problems related to the occupation such as the limited and small market and the connected and donordependent economy. Thus, a business incubator is a tool that can support entrepreneurs in establishing their start-up companies which then create more jobs. According to the National Business Incubation Association (NBIA), what can be achieved in business by entrepreneurs in three years can be achieved in only one year with support from a business incubator. Also, the success rate of new start-ups is higher through incubation [21].

Moreover, SMEs contribute more than $50 \%$ of global GDP, provide $40-80 \%$ of the total employment and help to reduce unemployment. For these reasons, some countries such as France and Malaysia did their best to support SMEs [30].

\section{Information and Communication Technologies (ICT)}

The term ICT is a combination of two terms: information technology (IT) and communications. Information technology refers to any computing technology, such as networks, hardware, software, communication devices, communication infrastructure, systems, and solutions, and the internet. Nowadays, most companies have an IT department to manage every process involving computers, programming, web development, networks, and other technical areas of their business. Therefore, IT has become a part of our everyday lives [1], [31].

Information and communication technologies allow access to information through telecommunications, so the term is similar to IT but is also concerned with communication technologies such as the internet, wireless networks, cell phones, voice over internet protocol, video conferencing, social networking sites such as Facebook, and other communication media.

The creation and development of new businesses has been encouraged by ICT, which offers a value proposition based on its application in areas such as selling online, outsourcing, and competitiveness. Information and communication technologies are considered to be tools that can increase productivity and transparency across all sectors including agribusiness and tourism. Since the advent of the internet, the development of ICT has led to major changes in society because the cheapness and affordability of IT products facilitates access to information beyond national borders [32], [33].

Therefore, using ICT in an effective way has become a core requirement for international competitiveness because it is critical in supporting and enhancing information sharing using new channels of communications instead of traditional ones. So business incubators play a critical role in providing access to these services in an effective way through the use of ICT tools and in teaching entrepreneurs and incubator staff how to use these tools and services efficiently [34].

According to [1], which proposes a survivability model for Saudi ICT start-ups, there is a need to conduct more research on Saudi ICT start-ups to study their success factors. In addition, "ICT start-ups are important to the economy because they are needed in the progression of all industries. They required less investment and less time to implement than businesses in other fields".

According to [35], argues that adopting ICT tools can dramatically improve international competitiveness. Also, using ICT tools can help to extend an organization's business and enable an organization to provide more comprehensive customer services and functions [36]. Moreover, [37] adds that using ICT tools in organizational processes can save a huge amount of time and money by decreasing the need to travel, as well as improve the efficiency and effectiveness of decision-making.

Currently, information is a crucial part of any organizational process, for example, information about customers, markets, competitors, procedures, products, etc., and the adoption of ICT tools can help organizations or companies to collect, process, store, and share that information [38].

Earlier, ICT tools were classified into three categories: computer technology, the internet, and telecommunications. Currently, ICT is classified into hardware, communication software, and office equipment [39], which are vast domains.

Based on the literature, [40] classifies ICT tools into five categories: (1) communication, which is divided into two types: synchronous such as Skype, MSN, and others; and asynchronous such as e-mail, Wiki, and others; (2) computing such as spreadsheets, data mining, and others; (3) course management such as learning management systems, content management systems, and others; (4) social networking such as Facebook, Twitter, and others; and (5) collaboration such as project management systems, workflow systems, and others.

\section{Success Factors}

Many studies have been conducted in developed countries on the factors involved in the success of business incubators, but only a limited number of studies have been conducted in developing countries including Arab countries, so more studies about incubator success are needed. Indeed, the authors of [19] state that they intend to conduct more case studies in different Middle Eastern and Gulf states to develop a blueprint to shape the twenty-first century. Moreover, [17] state that today, business incubators and SMEs still face many barriers in developing countries such as South Africa, where business failure and high unemployment persist. In [7] it is stated that researchers have focused on identifying the key success factors for 
business incubation. Key success factors are defined as the main dimensions of a firm's operations that are necessary to its success, so key success factors must work together consistently to ensure that incubated firms are successful, and these factors can vary across industries, product lines and other dimensions of strategic relevance [41], [42].

Reviews of the literature on business incubation have found that many different success criteria and case studies have been used. For instance, [7] found that early research focused primarily on case studies, defining the physical facilities for business incubators and best practice in particular industries, these case studies are not enough to adopt and have some difficulties in defining what constitutes success.

The following provides some information derived from the literature about the success factors selected for the research model developed by the current study:

1) Selection Policy: One of the most important processes in the success of a business incubator is how the incubator selects the firms it wishes to incubate, and this may vary with the mission and objectives of the incubator. In [43], the proposed business incubator model suggested that the selection and monitored application of business services are one of the four areas where incubators/incubation creates value.

Any incubator that seeks to be successful and to build sustainable companies must have good selection policies and rules in order to evaluate, recommend, and select tenant firms. Admission into an incubator is approved by the board of the incubator, the incubator manager, and the selection committee [44]. According to [45], a selection policy is concerned with how an incubator identifies new ventures that are weak but promising from those that cannot be incubated. As regards the selection criteria for incubatees, [45] states that they vary and differ between business incubators and that there is no agreed set of general effective criteria. It has also been claimed that one of the basic findings of incubator/incubation research is that variability in the incubatee screening and selection process can lead to incubator and/or incubatee failure [46].

As regards the responsibility for and the method of assessing new tenants, [8] found that, in the case of Jordanian business incubators, the selection process is often organized based on the project and the clients, using several criteria that depend on the role of each incubator, and the selection team usually includes the incubator manager, staff, and committee.

In the same context, [47] states that the incubator selection is mostly done through the incubator website, or by using the Canvas model to transform an idea into a business model, and in some cases is complemented by some financial statements.

2) Networking Services: Currently, due to the development and spread of ICT, networking is considered to be one of the most important factors in the success of incubators, firms, tenants, and businesses. In [43], the proposed business incubator model includes the provision of access to the incubator network as one of the four areas where incubators/incubation creates value.
Incubators support tenants and entrepreneurs to achieve their business objectives. Entrepreneurship is a dynamic process that requires links or relationships not only among individuals, but also among a variety of institutions. Through networking, the entrepreneur has access to more opportunities and will have a greater chance of solving his/her problems expeditiously, which will give him/her the chance to succeed in his/her new venture [44]. In support of this viewpoint, [48] states that networking is less dependent on specific individuals or entrepreneurs' personal connections; rather, it can be expanded to include numerous companies or other entities such as regulators, policy-makers and research institutions in many different sectors.

In [49], networking is defined as interconnected dyadic relationships, where these relationships are considered as a group of nodes that may take the form of roles, individuals or organizations. Hence, different network types can be defined by expressing different nodes (actors) and different relationships. Thus, according to this definition, business networking can be referred to as a set of two or more connected business relationships or firms [50].

Networks are crucial for the survival and growth of new ventures and SMEs as they provide information, knowledge and expertise as well as reduce the uncertainty that firms face [51]. Moreover, networking is considered as a cornerstone and mechanism for entrepreneurial businesses, and for nurturing relationships that provide access to necessary resources that can be fostered as part of incubation processes and promote business relationship building before the start-ups need these [52].

In the same context, networking enables entrepreneurs to evaluate with other entrepreneurs, get inspiration, develop common ideas and assess the performance of their business, and it can also strongly promote performance through innovation for commercialization and internationalization, inspiration, idea development, business development and assessment, knowledge sharing, skill acquisition, identification of core competencies, increased market share, and scientific research [53]. Furthermore, [10] considers networking services to be one of the most important elements of the incubation process.

3) Incubator Resources and Services: Considered one of the most important factors for the success of any incubated company, this factor relates to matters such as office space at favourable rents and access to a pool of shared resources such as receptionists and secretaries, meeting rooms, conference rooms, and car parking. These resources and services are offered by incubators at an inexpensive cost to reduce overhead costs and have received special attention in the literature [47], [54], [55].

Physical resources such as physical space and furniture are considered one of the important services offered by an incubator especially in the past, and continued until now with other supporting services. According to [7], business incubators have to provide tenants with affordable office space and a group of support services both through internal and external affiliates to increase the probability of business survival. In [8], it is stated that incubators for small businesses provide physical facilities such as office, warehousing, and manufacturing space, common loading docks, a shared board or meeting space, kitchen facilities, 
and a common reception area, including a shared copier, fax, audio-visual equipment, and often computers. Moreover, [56] reports that the Cooperative Department and Small Enterprises, and the Ministry of Cooperative and Small and Medium Enterprises of Indonesia state that space and shared office facilities and services are basics that all incubators should provide.

4) Funding and Support: Accessing and securing funds is the main target of incubators, and this way especially in the past when incubators first appeared. Funding supports business tenants that have a good idea but do not have enough money and know-how to achieve their aim. Incubators offer access to funding through their network of contacts and also offer financial training support in addition to offering actual funding, and some incubators can offer access to a range of governmental financing sources [13], [43], [46].

Access to financial resources is one of the key factors for the survival for most start-ups, for successful business incubation, and is regarded as one of the incubator effectiveness factors [13], [43], [57].

Incubators can be classified into four organizational types: (1) for-profit private or corporate, which are concerned with full incubation rather than job creation potential and have less focus on the entry criteria for tenant firms and are less likely to limit tenants' residency due to the financial risk associated with tenants' turnover; (2) not-for-profit public or government, which focus on job creation and economic development and limit the duration of tenant residency; (3) academic or educational institutions; and (4) hybrid public/private partnerships [9], [58], [59].

In the conceptual model of incubator effectiveness proposed in [57], many indicators are used to measure the factor of access to finance, such as the ability to access angel investors or an angel network, the ability to access venture capital investors, the ability to access in-house investment funding, help in accessing commercial loans, help with accounting or financial management, help in accessing specialized funds, and economic literacy training.

As reported in [56], according to the Bank Indonesia, lack of seed capital support means that incubators cannot do their job well, and it will affect the development of incubators in Indonesia. It was also found that a significant number of incubated tenants cannot obtain seed capital even though their business is feasible.

5) Mentoring Services: Mentors or advisors are senior men and woman who have different perspectives and important career experiences that can influence people in the early phases of their professional life, and they play a different role than peers or consultants [60]. Mentoring is very important because knowing one's tools is not enough; entrepreneurs need to be trained and taught how to "play the game" and how to utilize their tools effectively. In two incubators investigated by [60], entrepreneurs expressed a need for mentoring, so they could obtain new ideas and feedback from mentors and incubator manager, this way considered one of the most effective ways for entrepreneurs to develop their needs and ideas.

In [61], mentoring is defined as a process of informal communication, usually face-to-face and over a sustained period of time, between a mentor (a person who is perceived to have greater relevant knowledge, wisdom, or experience) and a tenant who is perceived to have less to transfer in terms of knowledge, social capital, and psychosocial support.

Many studies mention that mentoring is one of the important newer services that incubators offer to tenants. Office sharing, financial support, business mentoring, coaching, and training are all important facilities and factors that are offered by incubators to support the life of new startups [55], [62], [63].

For many years, the tangible elements of incubator resources were used as indicators for success, but recently the focus has shifted to intangible factors, such as entrepreneurial networking, mentoring, and coaching, which enhance access to various forms of capital, such as social, human, and financial [7], [64]. Furthermore, [47] considers that mentoring is one of the important services that incubators can offer to entrepreneurs.

6) Incubator Governance: The management team and staff are one of the most important parts of any organization in terms of success and competitiveness. Having an incubator governance structure is very important. This structure usually consists of an experienced incubator manager, a key board of directors, a noted advisory council, and concise program milestones with clear policies and procedures. This type of governance plays an important role in recommending, reviewing, evaluating, and selecting tenants [9], [11], [13], [15], [44], [57], [58], [65]-[67].

The executive board or board of directors usually consists of investors, financial contributors, business individuals, as well as experts and technical individuals who can help in setting policies [9], [58].

In addition, [7] states that in a university-based incubator, the incubator manager considers a high survival rate as the key criterion for success. On the other hand, the management team of a private incubator is concerned with the incubator's own investment in new companies and the team participates in all the aspects of the daily management of operational activities, whereas the management of public incubators acts as an intermediary [11], [13].

Incubator governance is very important in the incubation process because incubated companies always need to know what will be expected of them, how they should perform, how they will be evaluated, what the daily procedures, activities, and policies are, and what the incubator will provide. Moreover, and any emerging company will experience problems and uncertainties. Whether and how rapidly incubated companies develop depends on the relationship between the types of governance and the types of entrepreneur in the incubated companies [9], [44]. Thus, concentrating on intangible business services and employing qualified managers and support staff will increase the possibility of incubator success and help start-ups in creating, growing, and developing their business [7].

7) Corporate Culture: One of the main key factors that is used a lot in the assessment of organizational performance and success is that of culture. As mentioned earlier, many researchers define incubators as organizations. However, in the literature, culture is not considered to be one of the key factors in incubator success; rather key persons and 
incubator managers consider it to be one as revealed in the results of the e-mail interviews conducted by the researcher for the current study.

There are many different ways to define cultures in various research fields, such as sociology, anthropology, and the humanities. For instance, [68] defines culture as something that is inherited from people minds, and is influenced directly and indirectly by society and can be programmed into the human mind early in life. Others define culture as a shared system of beliefs and values that have an effect on the behavior of organizational managers and stakeholders [69], [70].

Corporate culture, which is a rich system of values and beliefs, is a very important driver in building a corporate identity and is a key indicator in building and securing corporate reputation [69], as summarized from many types of research study.

Many types of culture can be found in the literature, such as organizational culture, entrepreneurial culture, innovation culture, and risk-taking culture. A good understanding of these types of cultures are very important for all leaders because it has an effect on the way that their organizations react to the changing demands of the business environment, and is strongly influenced by past successes and past learnings about how to adapt and survive [71].

In addition, [72] states that many types of research study in many countries have examined the positive relationship between organizational culture and corporate performance, and this relationship is very important because it influences how people use company resources in an innovative way. Likewise [73] adds that innovation in any company is not just about the company's resources, technology, acquisitions, or people; there also needs to be a culture to support it and which can force employees to let go of old values and beliefs and instead adopt new ones, which is not an easy process.

\section{E. The Problem Statement}

As mentioned in the introduction, developing countries, especially Arab countries, are facing a very bad economic situation, which is making the unemployment rate very high compared to that in developed countries. Moreover, the GDP in Arab countries is very low compared to that in developed countries. In Palestine specifically, there are many incubation programs running that are offering good facilities and business services to entrepreneurs. In addition, thousands graduate every year; around 36830 students graduated last year from Palestinian universities [74]. Furthermore, thousands of innovation ideas are presented by Palestinian university graduates and entrepreneurs every year. However, the impact of incubators and incubation programs in Palestine on the number of jobs created and the value of GDP has been limited and there have only been a few success stories. One of the proposed solutions to these issues is to create jobs through SMEs that have graduated from an incubator [4], [10], [56].

In the case of developed countries, such as the USA and those in Europe, and others, many types of research and case studies have reported incubator success, but in developing countries such as those in the Middle East and North Africa, there is still a limited number of research studies, including case studies, on this issue [7], [8], [75]. This research intends fill this gap in the literature. Information and communication technologies are crucial tools that are used in daily life and can encourage the creation and development of new businesses [1], [31], [34]. So, the current study will attempt to investigate this important factor in the success of incubators.

\section{F. Proposed Conceptual Model and Hypotheses}

Based on the results of a literature review and an interview survey conducted via e-mail with a group of incubator managers in Palestine a prior model (conceptual model) was developed for the current study, as shown in Fig. 3:

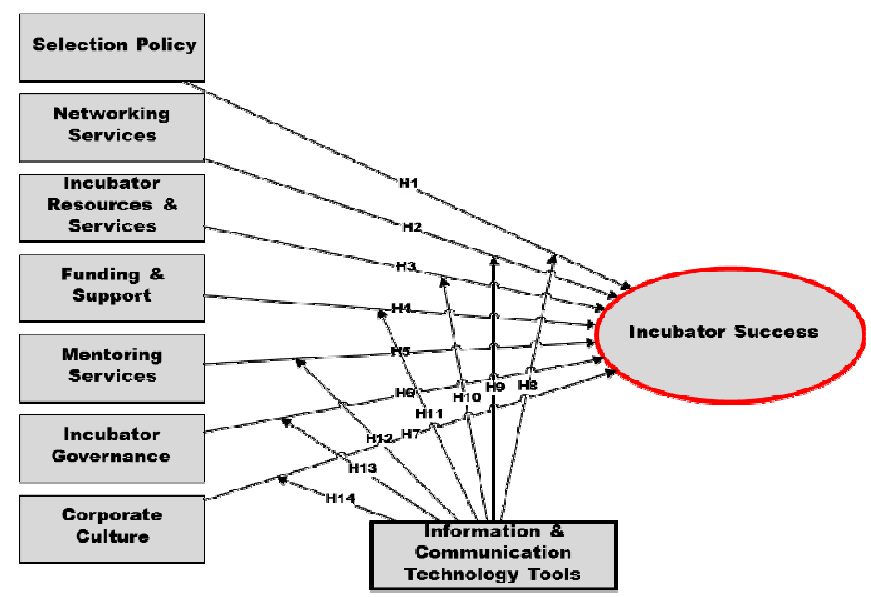

Fig. 3 Proposed conceptual model

- H1: There is a positive relationship between selection policy and incubator success.

- H2: There is a positive relationship between networking services and incubator success.

- H3: There is a positive relationship between incubator resources and services and incubator success.

- H4: There is a positive relationship between funding and support and incubator success.

- H5: There is a positive relationship between mentoring services and incubator success.

- H6: There is a positive relationship between incubator governance and incubator success.

- H7: There is a positive relationship between corporate culture and incubator success.

- H8: There is a positive relationship between selection policy, ICT tools and incubator success.

- H9: There is a positive relationship between networking services, ICT tools and incubator success.

- H10: There is a positive relationship between incubator resources and services, ICT tools and incubator success.

- H11: There is a positive relationship between funding and support, ICT tools and incubator success.

- H12: There is a positive relationship between mentoring services, ICT tools and incubator success.

- H13: There is a positive relationship between incubator governance, ICT tools and incubator success.

- H14: There is a positive relationship between corporate culture, ICT tools and incubator success. 


\section{RESULTS AND DISCUSSION}

This research attempts to bridge a gap in knowledge by providing research-based evidence on the relationship between incubators and economic development using a special model for incubator success especially in developing countries. The proposed model adopts many of the success factors that have been used in different case studies worldwide. Moreover, it combines these factors with feedback factors collected from interviews with key persons and managers in incubators in Palestine as a special case. The model also includes two additional factors, ICT tools and corporate culture, which are very important in our daily life. It hoped that the results of the study will make a practical contribution by providing guidance to incubator managers, governments, universities, centers of excellence, funded organizations, policy-makers, academics, and other stakeholders on how to ensure the future successful implementation of incubation programs in developing countries, and on how to encourage investors and capital investors to invest in these incubators.

\section{CONCLUSION}

Business incubators are one of the key elements in the entrepreneurship and economic development policies of any country and help to increase the creation of new firms and SMEs. Small and mid-sized enterprises play a very important role in enhancing innovation and economic development in developed and developing countries. They also contribute to job creation and minimizing unemployment in many countries.

The geopolitical and economic situation in developing countries, especially Arab countries, is both critical and challenging, and this has led to very high unemployment and very low GDP in these countries compared to developed countries. The use of ICT tools is very important for any organization wishing to increase competitiveness, save a lot of time and money, and improve the effectiveness of decision-making. In light of the issues highlighted in this paper, the current study aims to create a success factors model or framework for the good business incubator, and test it through incubators that are running in Palestine as a special case. Incubation models have been adapted to meet a variety of needs, such as increasing employment in economically distressed communities to serving as an investment vehicle and also helping in creating and supporting SMEs, which can help in creating jobs and enhancing innovation in products and services. Incubation models contain many success factors that are considered to be important services, resources, and policies used in the incubation process. If these factors are successful, the incubator and the entire incubation process will succeed. In the literature, there are many models that have been used successfully to measure incubator success and performance, but in developing countries only a few types of research study have been conducted on this topic, and there is therefore a need to conduct more.

\section{REFERENCES}

[1] S. Almakenzi, A. Bramantoro, and W. Rashideh, "A Survivability Model For Saudi Ict Start-Ups," International Journal of Computer Science \& Information Technology, vol. 7, p. 145, 2015.
[2] M. A. Khalil and E. Olafsen, "Enabling innovative entrepreneurship through business incubation," World, p. Page 69, 2010.

[3] J. M. Shepard, "Small business incubators in the USA: a historical review and preliminary research findings," Journal of Knowledgebased Innovation in China, vol. 5, pp. 213-233, 2013.

[4] H. M. Al-Mubaraki, A. H. Muhammad, M. Busler, A. Ahmed, and A. Ahmed, "Categories of incubator success: A case study of three New York incubator programmes," World Journal of Science, Technology and Sustainable Development, vol. 12, 2015.

[5] I. Alon and M. M. Godinho, "Business incubators in a developing economy: Evidence from Brazil's northeast region," Science and Public Policy, p. scw008, 2016.

[6] C. Mason, L. Jones, and S. Wells, "The City's role in providing for the public equity financing needs of UK SMEs," The City's Role in Providing for the Public Equity Financing Needs of UK SMEs, 2010.

[7] N. Theodorakopoulos, N. K. Kakabadse, and C. McGowan, "What matters in business incubation? A literature review and a suggestion for situated theorising," Journal of Small Business and Enterprise Development, vol. 21, pp. 602-622, 2014.

[8] E. Elmansori, "Business incubators in the Arab World: Comparative study of Jordan and UAE business incubators," World Journal of Science, Technology and Sustainable Development, vol. 11, pp. 282293, 2014.

[9] S. Verma, "Success factors for business incubators: an empirical study of canadian business incubators," Master, Management Studies, Carleton University, Ottawa, Ontario, 2004.

[10] O. Sungur, "Business Incubators, Networking and Firm Survival: Evidence from Turkey," International Journal of Business and Social Science, vol. 6, 2015.

[11] P. Shannxi, "Incubators, SMEs, and Economic Development of China," International Journal of Multimedia and Ubiquitous Engineering, vol. 11, No.1 (2016), pp. 311-318, 2016.

[12] T. Ramayah, N. S. Ling, S. K. Taghizadeh, and S. A. Rahman, "Factors influencing SMEs website continuance intention in Malaysia," Telematics and Informatics, vol. 33, pp. 150-164, 2016.

[13] R. Grimaldi and A. Grandi, "Business incubators and new venture creation: an assessment of incubating models," Technovation, vol. 25, pp. 111-121, 2005.

[14] H. M. Al-Mubaraki and M. Busler, "Business Incubators Findings from a Worldwide Survey, and Guidance for the GCC States," Global Business Review, vol. 11, pp. 1-20, 2010.

[15] N. Dee, D. Gill, T. Livesey, and T. Minshall, "Incubation for growth: A review of the impact of business incubation on new ventures with high growth potential," NESTA, 2011.

[16] H. M. Al-Mubaraki and M. Busler, "Entrepreneurship, Innovation, Incubator and Economic Development: A Case Study," World Academy of Science, Engineering and Technology, vol. 7, pp. 10821087, 2013.

[17] T. Lose and R. K. Tengeh, "The Sustainability and Challenges of Business Incubators in the Western Cape Province, South Africa," Sustainability, vol. 7, pp. 14344-14357, 2015.

[18] J. Hong and J. Lu, "Assessing the effectiveness of business incubators in fostering SMEs: evidence from China," International Journal of Entrepreneurship and Innovation Management, vol. 20, pp. 45-60, 2016.

[19] P. Allam Ahmed, H. Mubarak AL-Mubaraki, and M. Busler, "Incubator successes: lessons learned from successful incubators towards the twenty-first century," World Journal of Science, Technology and Sustainable Development, vol. 11, pp. 44-52, 2014.

[20] H. Al-Mubaraki and H. Schrödl, "Incubating success towards Gulf cooperation council (GCC)," International Journal of Innovation and Knowledge Management in Middle East \& North Africa, vol. 1, pp. 31-56, 2012.

[21] NBIA. (2015, 8/4/2015). Incubation Definition. Available: http://www.nbia.org/

[22] V. RYZHONKOV. (2013, 1/12/2015). Analysis of 20 Business Incubation Models. Blog 2015. Available: https://worldbusinessincubation.wordpress.com/2013/11/28/907/

[23] P. Voisey, L. Gornall, P. Jones, and B. Thomas, "The measurement of success in a business incubation project," Journal of Small Business and Enterprise Development, vol. 13, pp. 454-468, 2006.

[24] F. A. Khalid, D. Gilbert, and A. Huq, "Third-generation business incubation practices in Malaysian ICT incubators-a bridge too far?," American Journal of Management, vol. 12, pp. 88-107, 2012.

[25] Ö. Ç. Özdemir and Y. Şehitoğlu, "Assessing the Impacts of technology business incubators: A framework for technology 
development centers in Turkey," Procedia-Social and Behavioral Sciences, vol. 75, pp. 282-291, 2013.

[26] T. O'neal, "Evolving a Successful University-Based Incubator: Lessons Learned From the UCF Technology Incubator," Engineering Management Journal, vol. 17, 2005.

[27] J. P. Eshun Jr, "Business incubation as strategy," Business Strategy Series, vol. 10, pp. 156-166, 2009.

[28] Entrepreneur. (2015, 11/4/2015). Available: http://www.entrepreneur.com/encyclopedia/business-incubator

[29] N. Mahmud and M. F. Hilmi, "Total Quality Management (TQM), innovation and Malaysian SMEs Performance: Result from a pilot survey," in The 8th International Conference for Entrepreneurship, Innovation and Regional Development., 2015, p. 365.

[30] N. R. A. El-Naby and Y. H. Ashour, "Prioritizing Critical Success Factors for Incubated Information and Communications Technology Enterprises in Gaza Using Analytical Hierarchy Process (AHP)," 2015.

[31] TechTerms. (2015, 6/5/2015). Available: http://www.techterms.com

[32] V. Veronice, Y. Yelfiarita, and D. Darnetti, "Analysis of Characteristics Extension Workers to Utilization of Information and Communication Technology," International Journal on Advanced Science, Engineering and Information Technology, vol. 5, pp. 303305, 2015.

[33] V. Veronice, "Analysis Level Of Utilization Information And Communication Technology With The Competency Level Of Extension Workers," International Journal on Advanced Science, Engineering and Information Technology, vol. 5, pp. 226-229, 2015.

[34] InfoDev, "ICT-enabled Business Incubation Program: Strengthening Innovation at the Grassroots " June 20092009.

[35] K. Hoffman, "Microelectronics, international competition and development strategies: The unavoidable issues-Editor's introduction," World Development, vol. 13, pp. 263-272, 1985.

[36] M. Skibniewski and P. Nitithamyong, "Web-based construction project management systems: Practical advantages and disadvantages," in Proceedings of the 4th International Conference on Construction Project Management (ICCPM), Singapore, 2004.

[37] G. Bafoutsou and G. Mentzas, "Review and functional classification of collaborative systems," International journal of information management, vol. 22, pp. 281-305, 2002.

[38] C. Lopez-Nicolas and Á. L. Meroño-Cerdán, "The impact of organizational culture on the use of ICT for knowledge management," Electronic Markets, vol. 19, pp. 211-219, 2009.

[39] A. S. Sohal, S. Moss, and L. Ng, "Comparing IT success in manufacturing and service industries," International Journal of Operations \& Production Management, vol. 21, pp. 30-45, 2001.

[40] J. Li, "Identifying success factors that influence the adoption process of ICT tools in China's SOEs and POEs," 2012.

[41] S. S. Lee and J. S. Osteryoung, "A comparison of critical success factors for effective operations of university business incubators in the United States and Korea," Journal of small business management, vol. 42, pp. 418-426, 2004.

[42] S. Vij and H. Jhanji, "Business Incubation: A Review of Research Orientations, Impacts and Determinants of Success," in Proceedings of the Tenth Biennial Conference on Entrepreneurship, EDI Ahmadabad, 2013.

[43] C. Campbell, R. C. Kendrick, and D. S. Samuelson, "Stalking the latent entrepreneur: business incubators and economic development," Economic Development Review, vol. 3, pp. 43-49, 1985.

[44] R. W. Smilor, "Managing the incubator system: critical success factors to accelerate new company development," Engineering Management, IEEE Transactions on, pp. 146-155, 1987.

[45] S. M. Hackett and D. M. Dilts, "A systematic review of business incubation research," The Journal of Technology Transfer, vol. 29, pp. 55-82, 2004.

[46] D. F. Kuratko and W. R. LaFollette, "Small business incubators for local economic development," Economic Development Review, vol. 5, p. 49, 1987.

[47] L. M. C. Carvalho and S. V. Galina, "The role of business incubators for start-ups development in Brazil and Portugal," World Journal of Entrepreneurship, Management and Sustainable Development, vol. 11, pp. 256-267, 2015.

[48] M. T. Hansen, H. W. Chesbrough, N. Nohria, and D. N. Sull, "Networked incubators," Harvard business review, vol. 78, pp. 74-84, 2000 .

[49] B. Johannisson, "Networking and entrepreneurial growth," Handbook of entrepreneurship, pp. 368-386, 2000.
[50] Y. Kajikawa, Y. Takeda, I. Sakata, and K. Matsushima, "Multiscale analysis of interfirm networks in regional clusters," Technovation, vol. 30, pp. 168-180, 2010.

[51] S. Collinson and G. Gregson, "Knowledge networks for new technology-based firms: an international comparison of local entrepreneurship promotion," R\&D Management, vol. 33, pp. 189208, 2003.

[52] C. Roseira, C. Ramos, F. Maia, and S. Henneberg, "Understanding Incubator Value-A Network Approach to University Incubators," Universidade do Porto, Faculdade de Economia do Porto2014.

[53] E. Inanga and E. Azih, "Performance Effectiveness of Technology Incubation in Nigeria," Bus Eco J, vol. 5, p. 2, 2014.

[54] A. Bergek and C. Norrman, "Incubator best practice: A framework," Technovation, vol. 28, pp. 20-28, 2008.

[55] E. Commission, "Has the ERDF successfully supported the development of business incubators?," 2014

[56] L. Gozali, M. Masrom, and T. Y. M. Z. Haron, "Critical Success Factors of Successful E-Business Incubators Framework in Indonesian Public Universities," 2015

[57] A. D. Lish, "Antecedents of business incubator effectiveness: An exploratory study," Nova Southeastern University, 2012

[58] D. Allen, "Small business incubators and enterprise development (Report prepared for the US Department of Commerce)," University Park, PA: Pennsylvania State University, 1985.

[59] L. Peters, M. Rice, and M. Sundararajan, "The role of incubators in the entrepreneurial process," The Journal of Technology Transfer vol. 29, pp. 83-91, 2004.

[60] G. A. Lichtenstein, "The significance of relationships in entrepreneurship: A case study of the ecology of enterprise in two business incubators," 1992.

[61] A. C. De Beer, "Networking skills of government-funded incubator managers as perceived by incubatees," 2012.

[62] H. M. Al-Mubaraki and M. Busler, "The incubators economic indicators: Mixed approaches," Journal of Case Research in Business and Economics, vol. 4, p. 1, 2012.

[63] G. D. G. R. N. M. P. Vanrie, "The Smart Guide to Innovation-Based Incubators (IBI)," 2010.

[64] A. Tola and M. V. Contini, "From the diffusion of innovation to tech parks, business incubators as a model of economic development: the case of "Sardegna Ricerche"," Procedia-Social and Behavioral Sciences, vol. 176, pp. 494-503, 2015.

[65] N. O. Obaji, A. A. Senin, and C. K. Richards, "The Moderating Role of Government Policy on the Success of Business Incubation Programme," presented at the Asia Pacific Industrial Engineering and Management System, 2013.

[66] N. O. Obaji, A. A. Senin, and C. K. Richards, "The Nigerian Business Incubation Programme: The Moderating Role of Government Policy," Industrial Engineering and Management, vol. 13,2014

[67] P. S. G. Roberta Bocconcelli, P. Dr Håkan Håkansson, and C. Cantù, "A service incubator business model: external networking orientation," IMP Journal, vol. 9, pp. 267-285, 2015

[68] G. Hofstede, G. J. Hofstede, and M. Minkov, Cultures and organizations: Software of the mind vol. 2: Citeseer, 1991.

[69] Z. Abdullah and Y. Abdul Aziz, "Institutionalizing corporate social responsibility: effects on corporate reputation, culture, and legitimacy in Malaysia," Social Responsibility Journal, vol. 9, pp. 344-361, 2013.

[70] A. Kaasa, "Culture as a Possible Factor of Innovation: Evidence from the European Union and Neighboring Countries," in $R e$ thinking Diversity, ed: Springer, 2016, pp. 83-107.

[71] D. R. Denison and W. S. Neale, "Denison organizational culture survey," Ann Arbor, MI: Aviat, 1996.

[72] X. Cui and J. Hu, "A literature review on organization culture and corporate performance," International Journal of Business Administration, vol. 3, p. 28, 2012.

[73] S. Blank, "Hacking a Corporate Culture: Stories, Heroes and Rituals in Startups and Companies," vol. 2016, ed. Steve Blank Blog: Steve Blank, 2015.

[74] PCBS. (2015, 8/4/2015). Available: http://www.pcbs.gov.ps

[75] E. A. M. Alshukri, "Palestinian experience in business incubators and their role in the development of new works for young people," presented at the Youth and Development in Palestine, Palestine, 2012 . 